\title{
Experimental study of concrete with Blended Cement with Accelerated Curing \& Formation of Mathematical Model
}

\author{
Mr. Shantanu Sureshrao Gholap ${ }^{1}$ \\ (Department of Civil Engineering, Vidya Pratishthans College Of Engineering / University of Pune, India)
}

\begin{abstract}
Traditionally, strength of concrete in construction work is evaluated in terms of its 28 days strength of cubes. This procedure requires 28 days of moist curing before testing as per IS: 516-1959[9]. This time duration may be considered as a long period. Hence, needs for an accelerated curing technique has arisen, where 28 days strength of concrete can be easily predicted. The main objective of this paper is to develop mathematical model, which gives relation between accelerated curing strength and normal curing strength for 7 and 28 days compressive strength. Boiling water curing at $100^{\circ} 3^{\circ} \mathrm{C}$ is applied to accelerate the strength gain of concrete for the early prediction of 7 days and 28 days compressive strength. Various concrete mixes in terms of cement $(O P C)$, cement replacing materials likes activated fly ash, Metakaolin were considered to prepared cubes.
\end{abstract}

Keywords: Accelerated curing, Activated fly ash, Concrete compressive strength, Flexural strength, Metakaolin

\section{Introduction}

Recent trend in engineering technology is to develop economic concrete and complete the project within time limit. To develop the economic concrete, mix design is to be developed and to complete project within time limit, the compressive strength of concrete cubes for selected mix design should be determined earlier in the laboratory.

The compressive strength of hardened concrete is most common property required for the structural use. The prediction of 28 days strength at early age is needed for different purpose such as,

$>$ The fast trend of construction progress and its economic benefits attained from accelerating construction schedule.

$>$ Testing for quality control purposes

$>$ To check the suitability of concrete mixes much earlier than 28 days test.

The rate of strength gain mainly depends upon the rate of hydration and the rate of hydration depends on the surrounding temperature. The strength gain could be accelerated at early age and related to 7days, 28 days and 56 days compressive strength.

Blended cements are produced by intimately and uniformly intergrinding or blending Ordinary Portland Cement (OPC) with one or more supplementary cementitious materials (SCMs). Most SCMs, such as ground granulated blast-furnace slag (GGBFS) or fly ash (FA), are industrial by-products. These materials are generally not used as cements by themselves, but when blended with OPC, they make a significant cementing contribution to the properties of hardened concrete through hydraulic or pozzolanic activity. Today, fly ash and bottom ash are being widely used in the construction industry. The use of fly ash is a well-established practice. The judicious use of fly ash results in reduced heat of hydration, increased later age concrete strengths. Coal fly ash is an abundant industrial waste product that happens to be high in reactive silica, and thus an excellent pozzolan. For this simple reason it is rapidly becoming a common ingredient in concrete all over the world; it is already present to some degree in half the concrete poured in the US. Particular interest to the industry is the idea of not just adding fly ash to known concrete mixes, but using large quantities to replace $30 \%, 50 \%$, or more of the portland cement-the glue-in a concrete mix. Most of the reasons for using fly ash in any proportion are practical, such as increasing strength and durability, decreasing heat of hydration.

Many reports published over the past decades, confirm the effectiveness of use of fly ash as replacement material in concrete. Fly ash used in concrete to reduce the heat of hydration of concrete but due to this resultantly there is reduction in early strength of concrete i.e. it requires more time to set also the use of fly ash has great influence on the mechanical properties of concrete. The great number of parameters that affect the concrete strength. These parameters are volume of fly ash used, presence of binder material, aggregate size, curing conditions, chemical effect, grade of concrete used and mixing proportions also. It is necessary to know the exact effect of different additive volume fraction and different curing conditions on mechanical properties of concrete. Such an evaluation is needed for developing the mathematical model of strength of concrete which will give us guidance of use of blended cement concrete and use accelerated curing methods. 


\subsection{Cement}

\section{Materials}

Ordinary Portland Cement (53 grade) confirming to IS: 12269-1987 was used for the experimental investigation. The cement was tested as per IS: 4031-1988.

\subsection{Fly Ash}

Fly Ash comprise of the non- combustible mineral portion of coal. Fly ash particles are glassy spherical shaped, ball bearings, finer than cement particles, which helps to reduce amount of water and improve workability. It also reduces heat of hydration and improves durability.

\subsection{Metakaolin}

It is highly pozzolanic material. It is obtained by calcinations of Algerian kaolin at $700^{\circ} \mathrm{C}$ for 7 hours. The silica and alumina contained in the metakaolin are active and react with free lime to form C-S-H and aluminasilicates which greatly improve the strength.

\subsection{Composition of Cement}

\section{Figures And Tables}

Table 1: Composition of different types of cement

\begin{tabular}{|l|l|}
\hline Type & Composition \\
\hline A & OPC \\
\hline B & $90 \%$ OPC $+10 \%$ Fly Ash \\
\hline C & $80 \%$ OPC $+10 \%$ Fly Ash $+10 \%$ Metakaolin \\
\hline D & $70 \%$ OPC $+20 \%$ Fly Ash $+10 \%$ Metakaolin \\
\hline E & $60 \%$ OPC $+30 \%$ Fly Ash $+10 \%$ Metakaolin \\
\hline
\end{tabular}

\subsection{Compressive strength test on concrete cube}

Total 45 concrete cubes were casted with five different mixes of cement. Then after 15 cubes were cured method of accelerated curing i.e. in boiling water for $3 \mathrm{hr}$ at $100{ }^{\circ} \mathrm{C}$ and 30 concrete cubes were cured by normal curing method i.e. 7 days and 28 days curing. The cubes are then tested to failure under gradually increasing load in CTM of capacity $1000 \mathrm{KN}$.

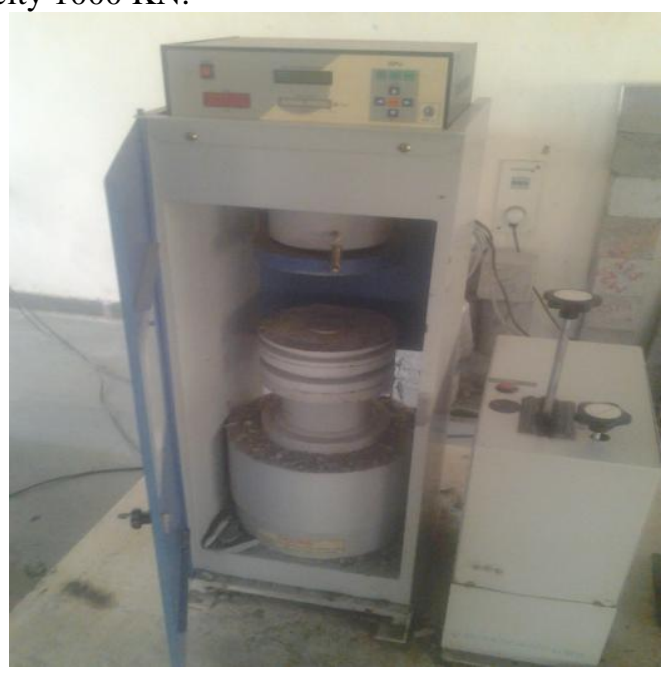

Fig. 1. shows compressive testing machine used to determine the compressive strength of plain concrete. The compressive strength of specimen will be calculated by following formula,

Where,

$$
f_{c k}=\mathrm{P} / \mathrm{A}
$$

$\mathrm{P}=$ Failure load in compression, $\mathrm{KN}$

$\mathrm{A}=$ Loaded area of cube, $\mathrm{mm}^{2}$ 
Table 2 : Compressive strength test values

\begin{tabular}{|c|c|c|c|c|c|c|}
\hline \multirow[t]{2}{*}{$\begin{array}{l}\text { Type Of } \\
\text { Cement }\end{array}$} & \multicolumn{4}{|c|}{ Compressive Strength $\left(\mathrm{N} / \mathrm{mm}^{2}\right)$} & \multicolumn{2}{|c|}{$\begin{array}{l}\text { Accelerated Compressive Strength } \\
\left(\mathrm{N} / \mathrm{mm}^{2}\right)\end{array}$} \\
\hline & $\begin{array}{l}\text { Failure Load } \\
(\mathrm{KN})\end{array}$ & 7 Days & $\begin{array}{l}\text { Failure Load } \\
(\mathrm{KN})\end{array}$ & 28 Days & Failure Load $(\mathrm{KN})$ & $\begin{array}{l}\text { Compressive } \\
\text { strength }\end{array}$ \\
\hline \multirow[t]{3}{*}{$\mathrm{A}$} & 485 & 21.56 & 756 & 33.6 & 868 & 38.57 \\
\hline & 523 & 22.24 & 774 & 34.4 & 905 & 40.22 \\
\hline & 492 & 21.87 & 767 & 34.08 & 900 & 40 \\
\hline \multirow[t]{3}{*}{$\mathrm{B}$} & 441 & 19.6 & 684 & 30.4 & 801 & 35.6 \\
\hline & 450 & 20 & 715 & 31.77 & 819 & 36.4 \\
\hline & 468 & 20.8 & 724 & 32.17 & 828 & 36.8 \\
\hline \multirow[t]{3}{*}{$\mathrm{C}$} & 372 & 16.53 & 571 & 25.37 & 761 & 33.82 \\
\hline & 390 & 17.33 & 603 & 26.8 & 790 & 35.11 \\
\hline & 372 & 16.53 & 578 & 25.68 & 772 & 34.31 \\
\hline \multirow[t]{3}{*}{$\mathrm{D}$} & 352 & 15.64 & 497 & 22.08 & 688 & 30.57 \\
\hline & 346 & 15.37 & 481 & 21.37 & 680 & 30.22 \\
\hline & 362 & 16.08 & 504 & 22.4 & 706 & 31.37 \\
\hline \multirow[t]{3}{*}{$E$} & 297 & 13.2 & 434 & 19.28 & 594 & 26.4 \\
\hline & 318 & 14.13 & 454 & 20.17 & 612 & 27.2 \\
\hline & 306 & 13.6 & 448 & 19.91 & 621 & 27.6 \\
\hline
\end{tabular}

3.2.1 The Mathematical model developed to show the relation between accelerated curing compressive strength and 7 days normal curing compressive strength for Type A (i.e. only OPC) is derived from following graph.

\section{TYPE A FOR 7 DAI}

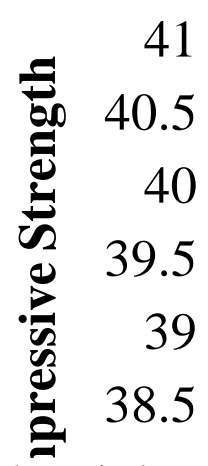

$$
\begin{gathered}
y=2.368 x-12.23 \\
R^{2}=0.809
\end{gathered}
$$

Fig 2 Mathematical Model of 7 Day Normal Compressive strength \& Accelerated Compressive strength

3.2.2 The Mathematical model developed to show the relation between accelerated curing compressive strength and 28 days normal curing compressive strength for Type A (i.e. only OPC) is derived from following graph.

\section{TYPE A FOR 28 DA}

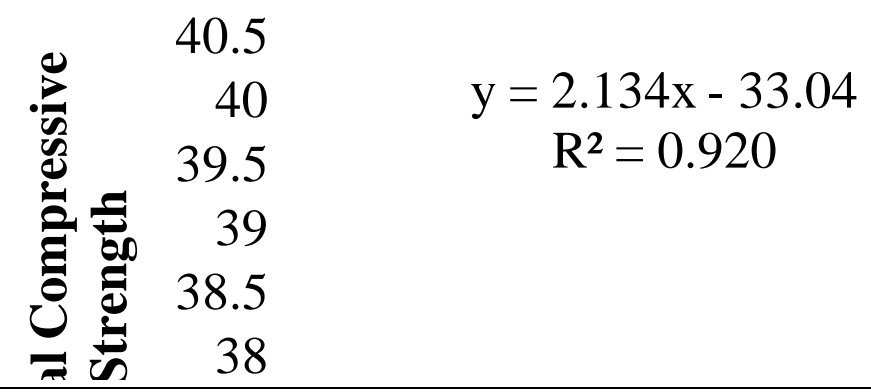


Experimental study of concrete with Blended Cement with Accelerated Curing \& Formation of...

Fig 3 Mathematical Model of 28 Day Normal Compressive strength \& Accelerated Compressive strength 3.2.3 The Mathematical model developed to show the relation between accelerated curing compressive strength and 7 days normal curing compressive strength for Type B cement is derived from following graph.

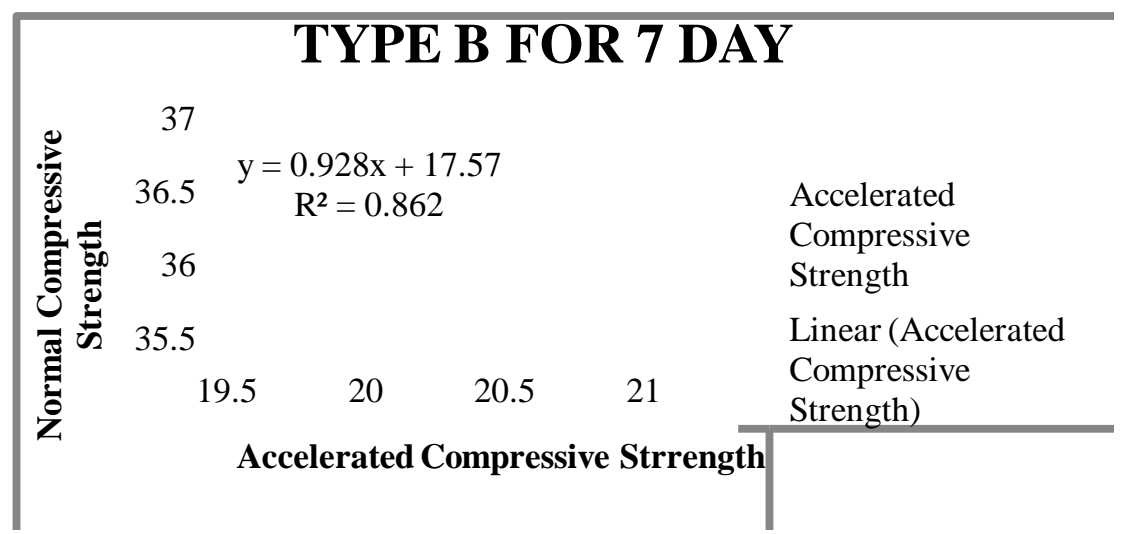

Fig 4 Mathematical Model of 7 Day Normal Compressive strength \& Accelerated Compressive strength 3.2.4 The Mathematical model developed to show the relation between accelerated curing compressive strength and 28 days normal curing compressive strength for Type B cement is derived from following graph.

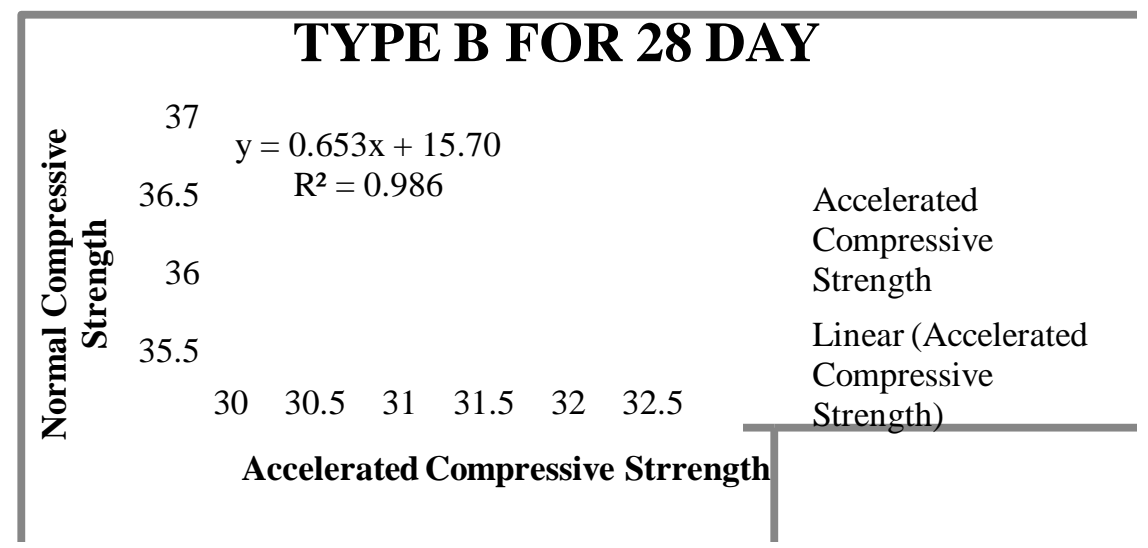

Fig 5 Mathematical Model of 28 Day Normal Compressive strength \& Accelerated Compressive strength 3.2.5 The Mathematical model developed to show the relation between accelerated curing compressive strength and 7 days normal curing compressive strength for Type $\mathrm{C}$ cement is derived from following graph.

\section{TYPE C FOR 7 DA}

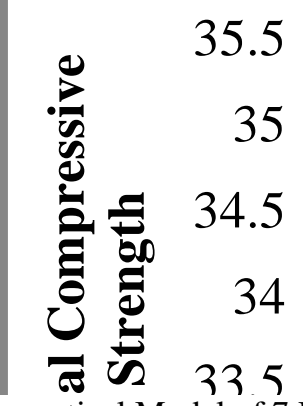

Fig 5 Mathematical Model of 7 Day Normal Compressive strength \& Accelerated Compressive strength

3.2.6 The Mathematical model developed to show the relation between accelerated curing compressive strength and 28 days normal curing compressive strength for Type $\mathrm{C}$ cement is derived from following graph. 


\section{TYPE C FOR 28 DA}

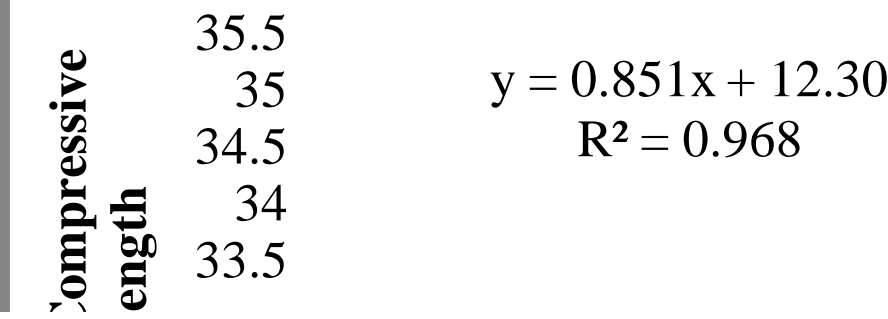

Fig 6 Mathematical Model of 28 Day Normal Compressive strength \& Accelerated Compressive strength

3.2.7 The Mathematical model developed to show the relation between accelerated curing compressive strength and 7 days normal curing compressive strength for Type $\mathrm{D}$ cement is derived from following graph.

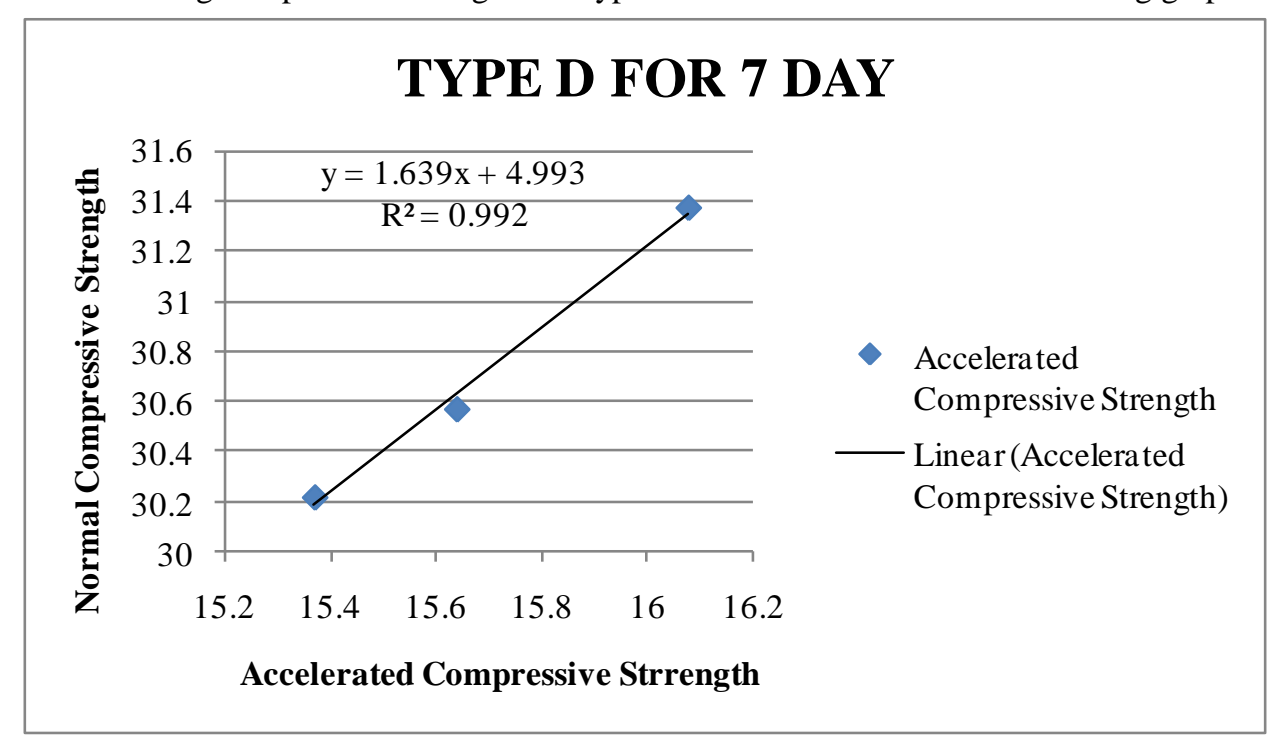

Fig 7 Mathematical Model of 7 Day Normal Compressive strength \& Accelerated Compressive strength

3.2.8 The Mathematical model developed to show the relation between accelerated curing compressive strength and 28 days normal curing compressive strength for Type $\mathrm{D}$ cement is derived from following graph.

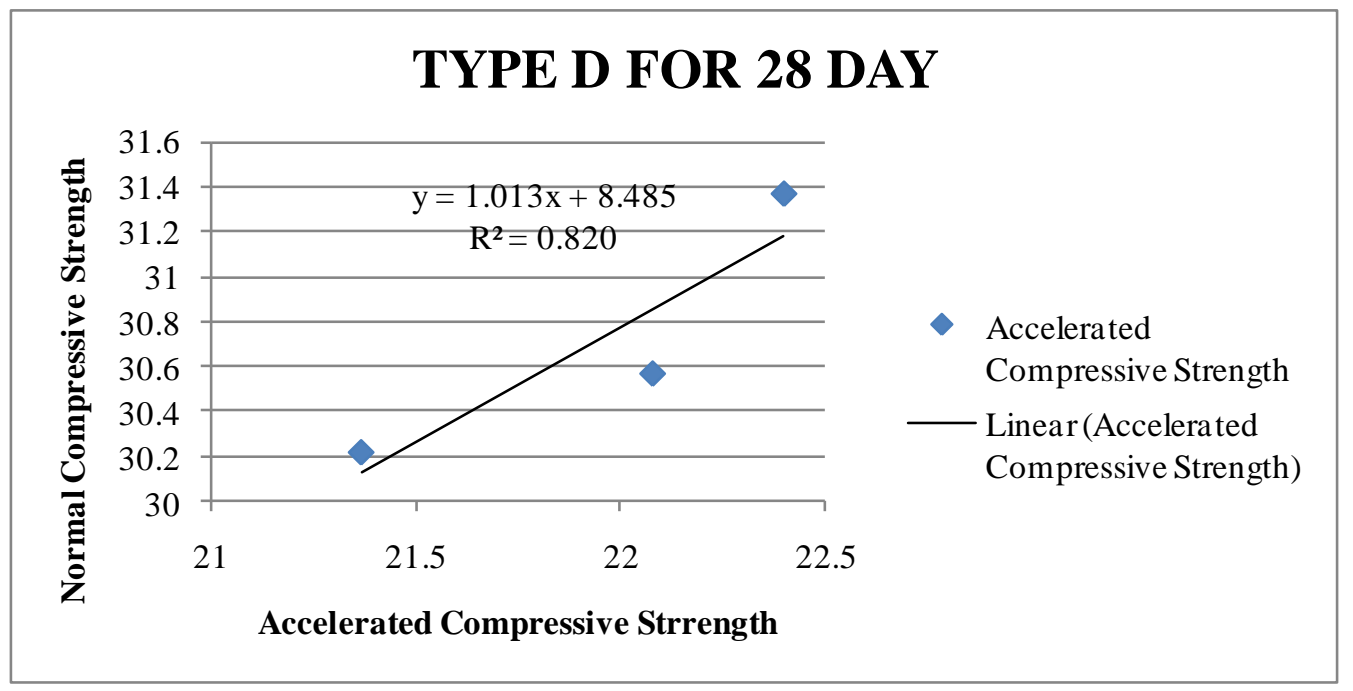

Fig 8 Mathematical Model of 28 Day Normal Compressive strength \& Accelerated Compressive strength 
Experimental study of concrete with Blended Cement with Accelerated Curing \& Formation of...

3.2.9 The Mathematical model developed to show the relation between accelerated curing compressive strength and 7 days normal curing compressive strength for Type E cement is derived from following graph.

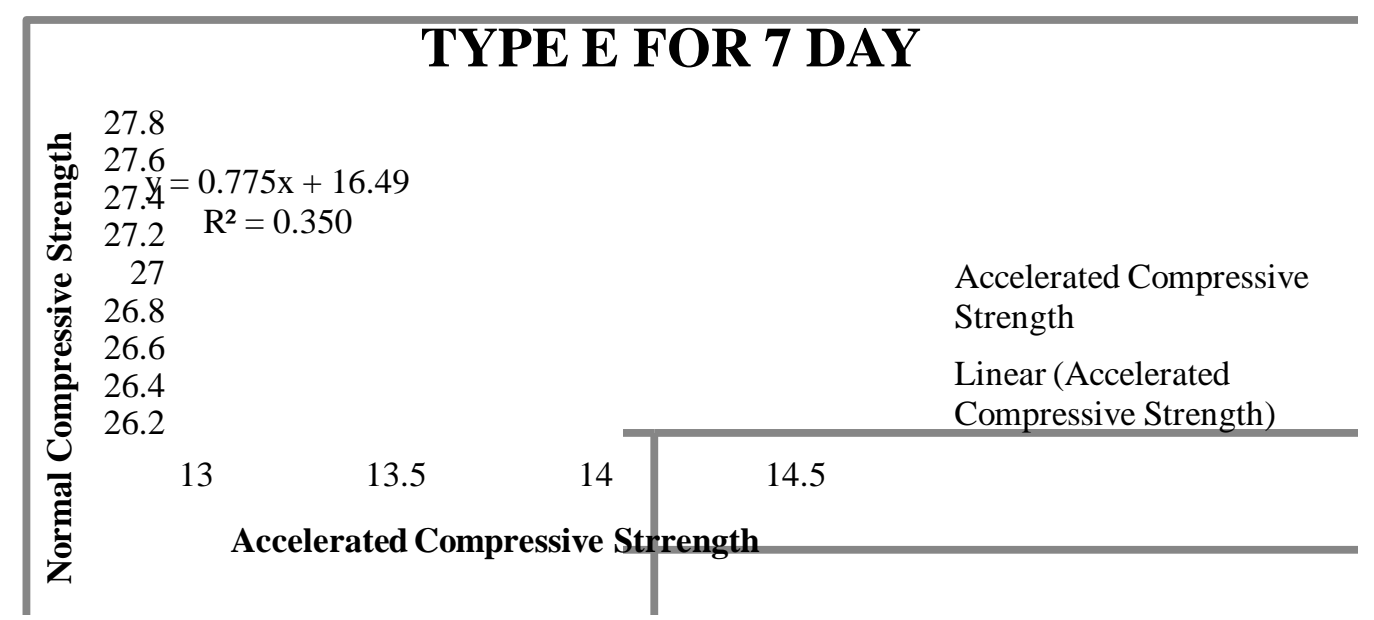

Fig 9 Mathematical Model of 7 Day Normal Compressive strength \& Accelerated Compressive strength

3.2.10 The Mathematical model developed to show the relation between accelerated curing compressive strength and 28 days normal curing compressive strength for Type E cement is derived from following graph.

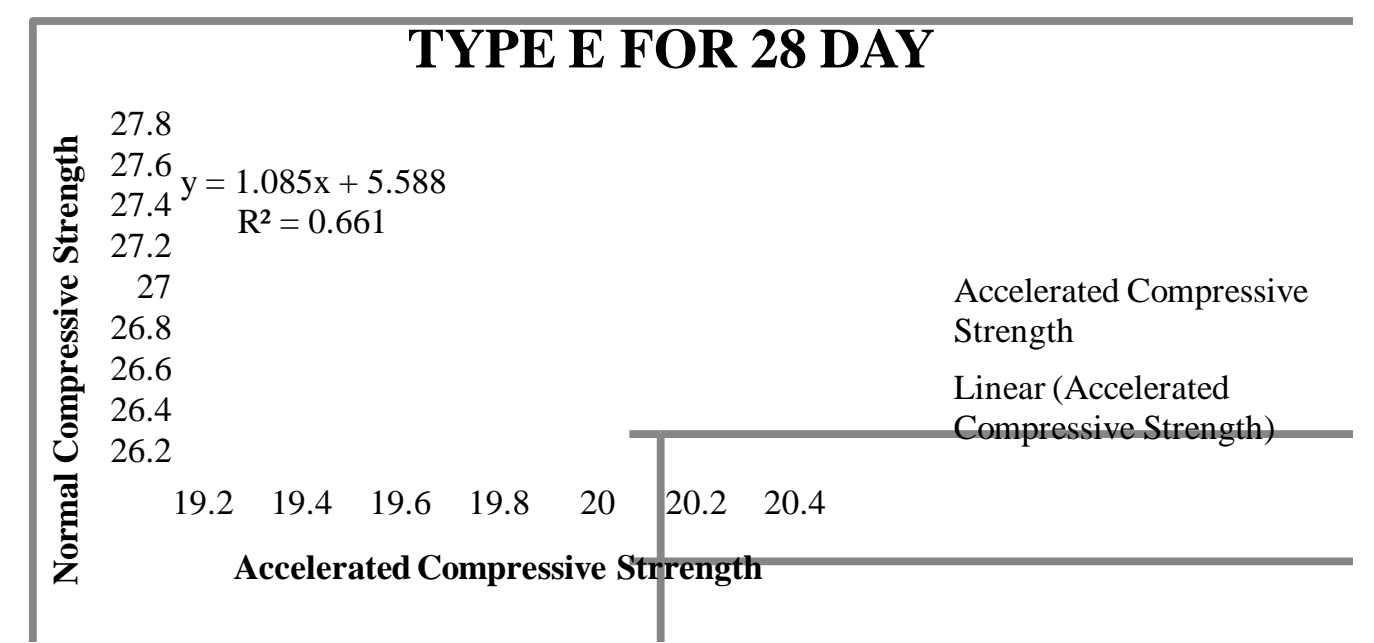

Fig 10 Mathematical Model of 28 Day Normal Compressive strength \& Accelerated Compressive strength

3.2.11 Relation between accelerated strength and normal curing strength at 7 days

Table 3 : Relation between accelerated strength and normal curing strength @ 7 days

\begin{tabular}{|c|c|}
\hline Type of Cement & Relation between accelerated strength and normal curing strength at 7 days \\
\hline A & $\mathrm{F}_{7}=2.368 \mathrm{~F}_{\text {acc }}-12.23$ \\
\hline B & $\mathrm{F}_{7}=0.928 \mathrm{~F}_{\text {acc }}+17.57$ \\
\hline C & $\mathrm{F}_{7}=1.306 \mathrm{~F}_{\text {acc }}+12.42$ \\
\hline D & $\mathrm{F}_{7}=1.639 \mathrm{~F}_{\text {acc }}+4.993$ \\
\hline & $\mathrm{F}_{7}=0.775 \mathrm{~F}_{\text {acc }}+16.49$ \\
\hline
\end{tabular}

3.2.12 Relation between accelerated strength and normal curing strength at 28 days

Table 4 : Relation between accelerated strength and normal curing strength @ 28 days

\begin{tabular}{|c|c|}
\hline Type of Cement & Relation between accelerated strength and normal curing strength at 7 days \\
\hline $\mathrm{A}$ & $\mathrm{F}_{28}=2.134 \mathrm{~F}_{\text {acc }}-33.04$ \\
\hline $\mathrm{B}$ & $\mathrm{F}_{28}=0.653 \mathrm{~F}_{\text {acc }}+15.70$ \\
\hline $\mathrm{C}$ & $\mathrm{F}_{28}=0.851 \mathrm{~F}_{\text {acc }}+12.30$ \\
\hline $\mathrm{D}$ & $\mathrm{F}_{28}=1.013 \mathrm{~F}_{\text {acc }}+8.485$ \\
\hline $\mathrm{E}$ & $\mathrm{F}_{28}=1.085 \mathrm{~F}_{\mathrm{acc}}+5.588$ \\
\hline
\end{tabular}


Experimental study of concrete with Blended Cement with Accelerated Curing \& Formation of...

3.2.13 The Mathematical model developed to show the relation between accelerated curing compressive strength and 7 days normal curing compressive strength for all types of blended cement is derived from following graph.

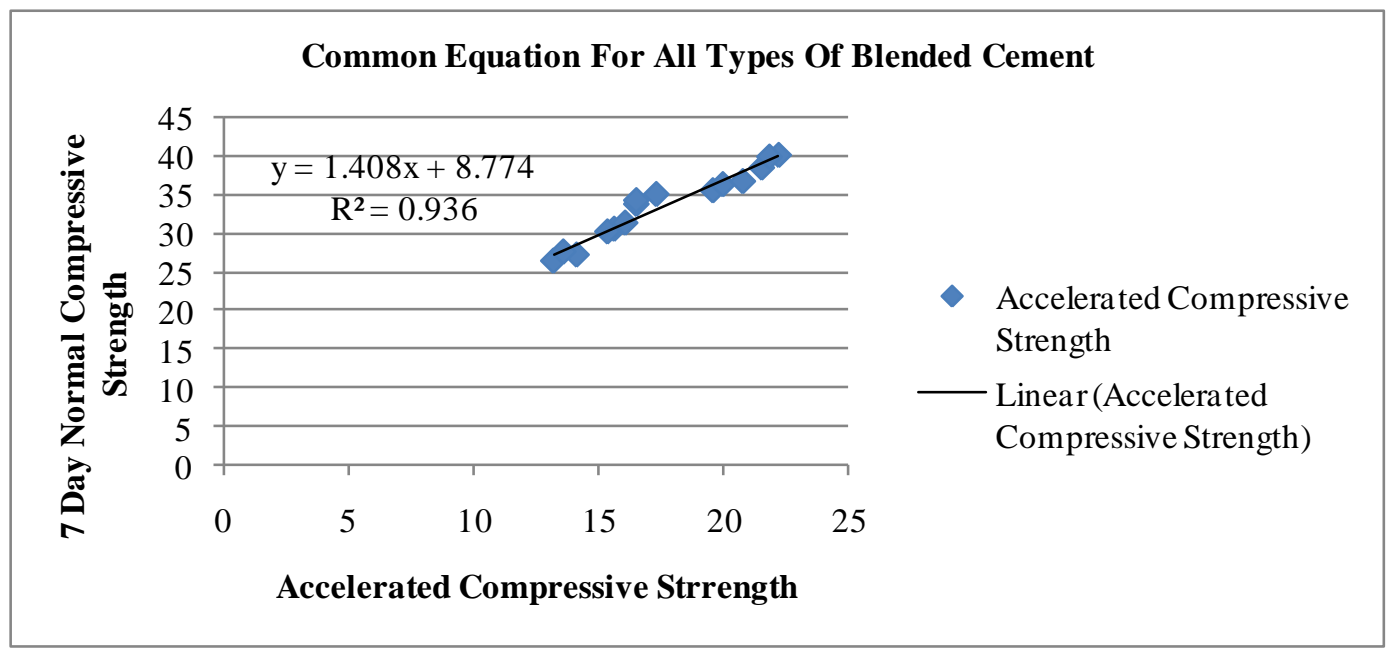

Fig 11 Mathematical Model of 7 Day Normal Compressive strength \& Accelerated Compressive strength

3.2.11 Relation between accelerated strength and normal curing strength at 7 days

Table 5 : Relation between accelerated strength and normal curing strength @ 7 days

3.2.14 The Mathematical model developed to show the relation between accelerated curing compressive strength and 28 days normal curing compressive strength for all types of blended cement is derived from following graph.

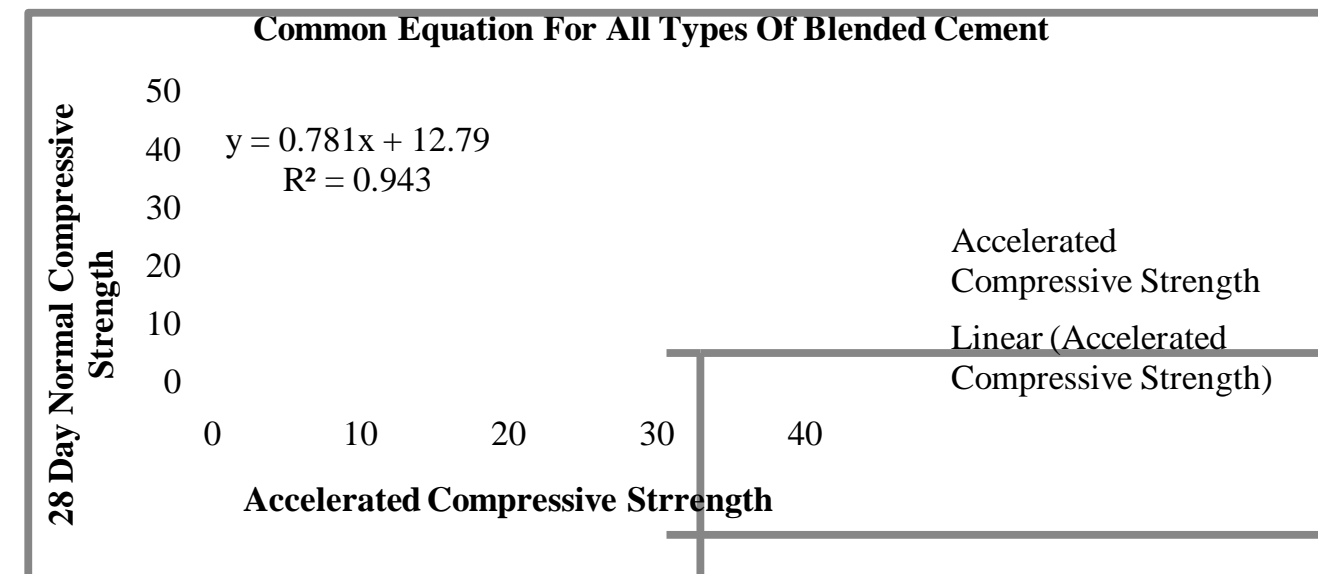

Fig 12 Mathematical Model of 28 Day Normal Compressive strength \& Accelerated Compressive strength

3.2.11 Relation between accelerated strength and normal curing strength at 28 days

Table 6 : Relation between accelerated strength and normal curing strength @ 28 days For all types of blended cement

\subsection{Flexural Strength of Beam Specimen}

After 28 days curing period, and accelerated curing period the two type test beam specimens were removed from the curing tank and both sides of the beam were white-washed to aid observations of the crack development during testing. The beams were tested to failure under gradually increasing load in a Universal Testing Machine (UTM). The capacity of Universal Testing Machine (UTM) is of $1000 \mathrm{KN}$. 


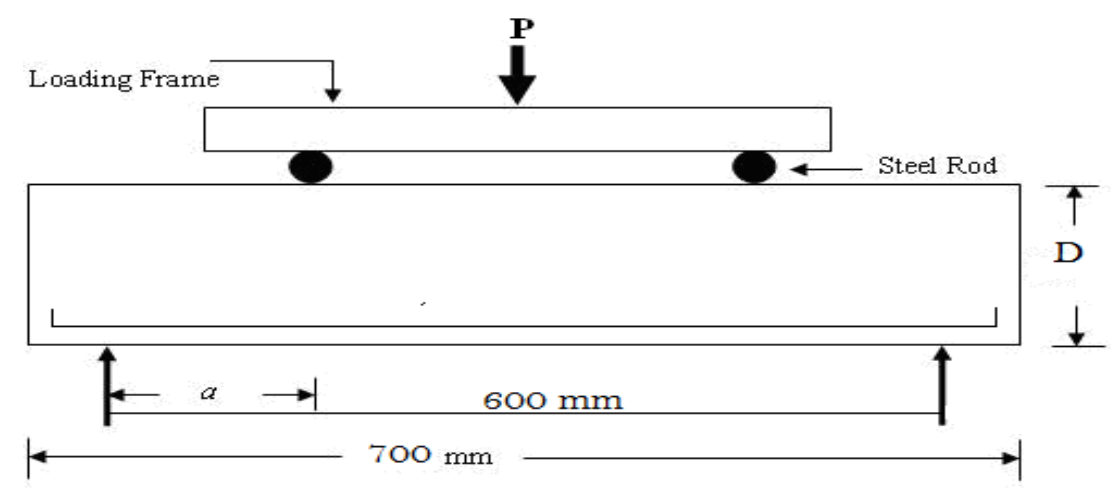

Fig. 13 Schematic representation of beam under four point loading

\subsection{Beam design}

Total 10 simply supported beams of normal size were tested up to failure. All specimens were of rectangular cross-section $150 \mathrm{~mm}$ breadth, $150 \mathrm{~mm}$ width \& $700 \mathrm{~mm}$ span. Two bars of $6 \mathrm{~mm}$ diameter were provided as longitudinal reinforcement. Grade of longitudinal reinforcement is Fe-500. Clear span of beam is $600 \mathrm{~mm}$ with clear cover $25 \mathrm{~mm}$.
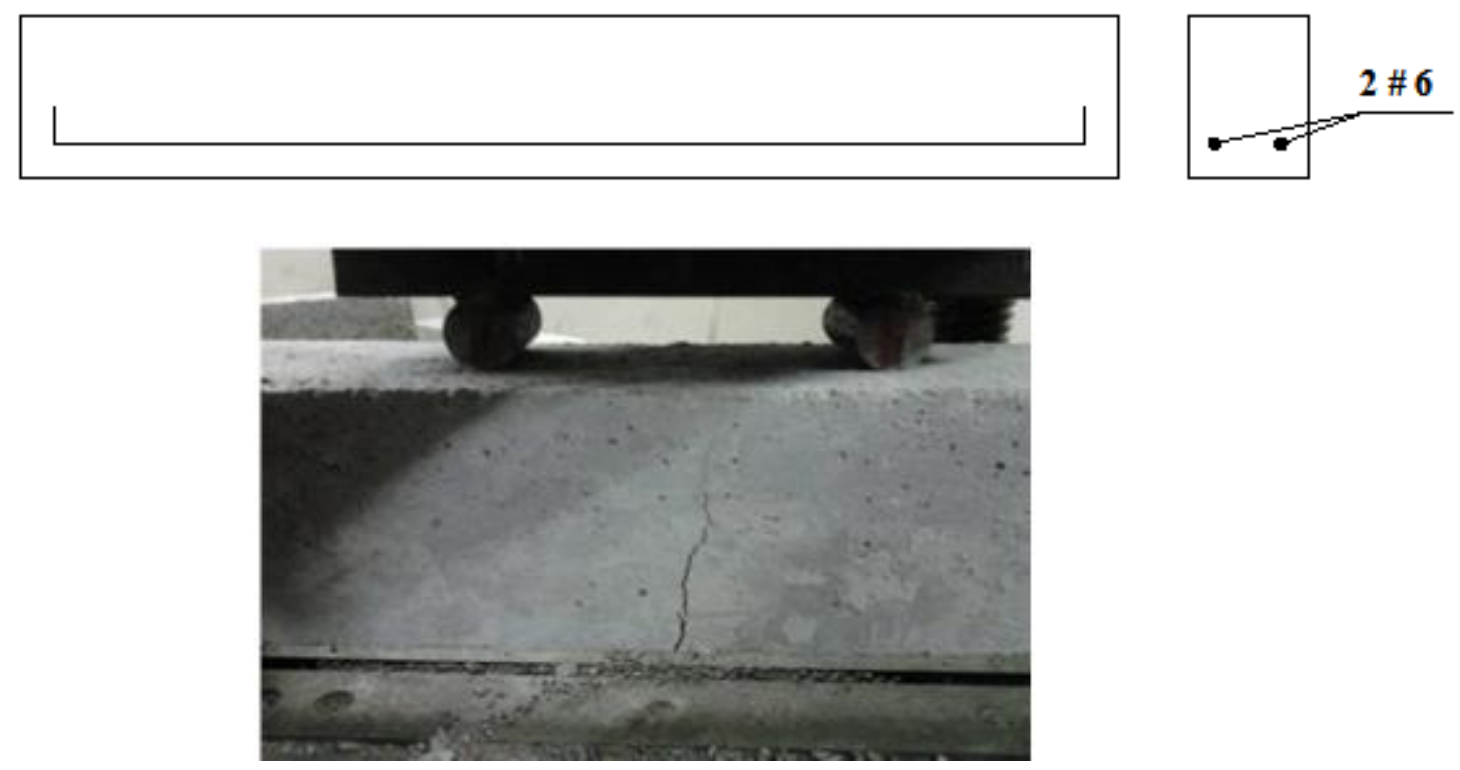

Fig 3 Beam specimen under UTM with four point loading

\subsection{Flexural strength test results}

Table 7 : Flexural strength test values

\begin{tabular}{|c|c|c|c|c|c|c|c|c|}
\hline \multirow{3}{*}{$\begin{array}{l}\text { Type of } \\
\text { cement }\end{array}$} & \multicolumn{4}{|c|}{ Normal 28 days curing } & \multicolumn{4}{|c|}{ Accelerated curing } \\
\hline & \multicolumn{3}{|c|}{ Fracture load $(\mathrm{KN})$} & \multirow{2}{*}{$\begin{array}{l}\text { Flexural } \\
\text { strength } \\
\left(\mathrm{N} / \mathrm{mm}^{2}\right)\end{array}$} & \multicolumn{3}{|c|}{ Fracture load $(\mathrm{KN})$} & \multirow{2}{*}{$\begin{array}{l}\text { Flexural } \\
\text { strength } \\
\left(\mathrm{N} / \mathrm{mm}^{2}\right)\end{array}$} \\
\hline & Trial - 1 & Trial - 2 & Avg. & & Trial - 1 & Trial - 2 & Avg. & \\
\hline A & 25.5 & 25 & 25.25 & 4.48 & 27 & 27.5 & 27.25 & 4.84 \\
\hline $\mathrm{B}$ & 27.5 & 27 & 27.25 & 4.84 & 29.5 & 29.5 & 29.5 & 5.24 \\
\hline $\mathrm{C}$ & 28 & 28.5 & 28.25 & 5.02 & 31.5 & 31 & 31.25 & 5.55 \\
\hline $\mathrm{D}$ & 23.5 & 23 & 23.25 & 4.13 & 25.5 & 25 & 25.25 & 4.48 \\
\hline $\mathrm{E}$ & 18.5 & 18 & 18.25 & 3.24 & 21.5 & 21 & 21.25 & 3.77 \\
\hline
\end{tabular}


3.5.1 The graph developed to show the variation of 28 days flexural strength depending on types of mixtures

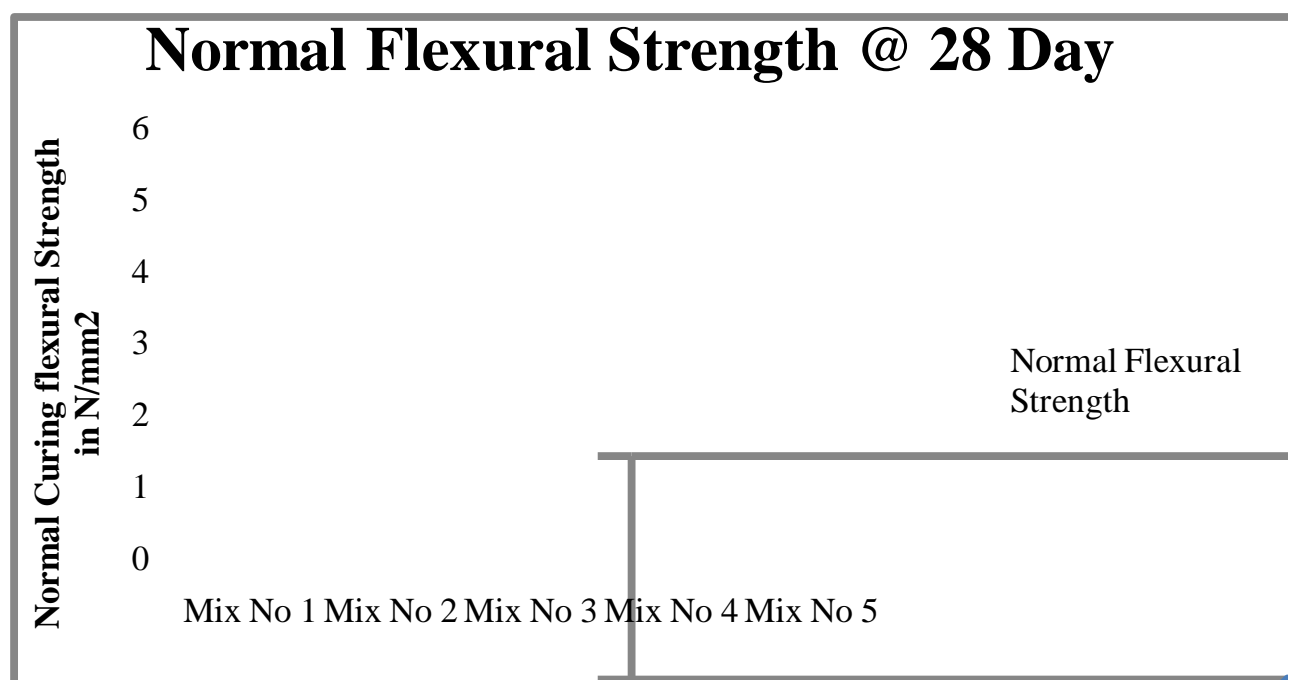

Fig 13 Variation of flexural strength with types of mixture @ 28 days normal curing

From Table 7 and Fig 13, it is observed that, the maximum value of flexural strength for 28 days normal curing $5.02 \mathrm{~N} / \mathrm{mm}^{2}$ is observed at Mixture No. 3 i.e. $10 \%$ Fly ash \& $10 \%$ Metakaolin and further it goes on decreasing

3.5.2 The graph developed to show the variation of accelerated curing flexural strength depending on types of mixtures

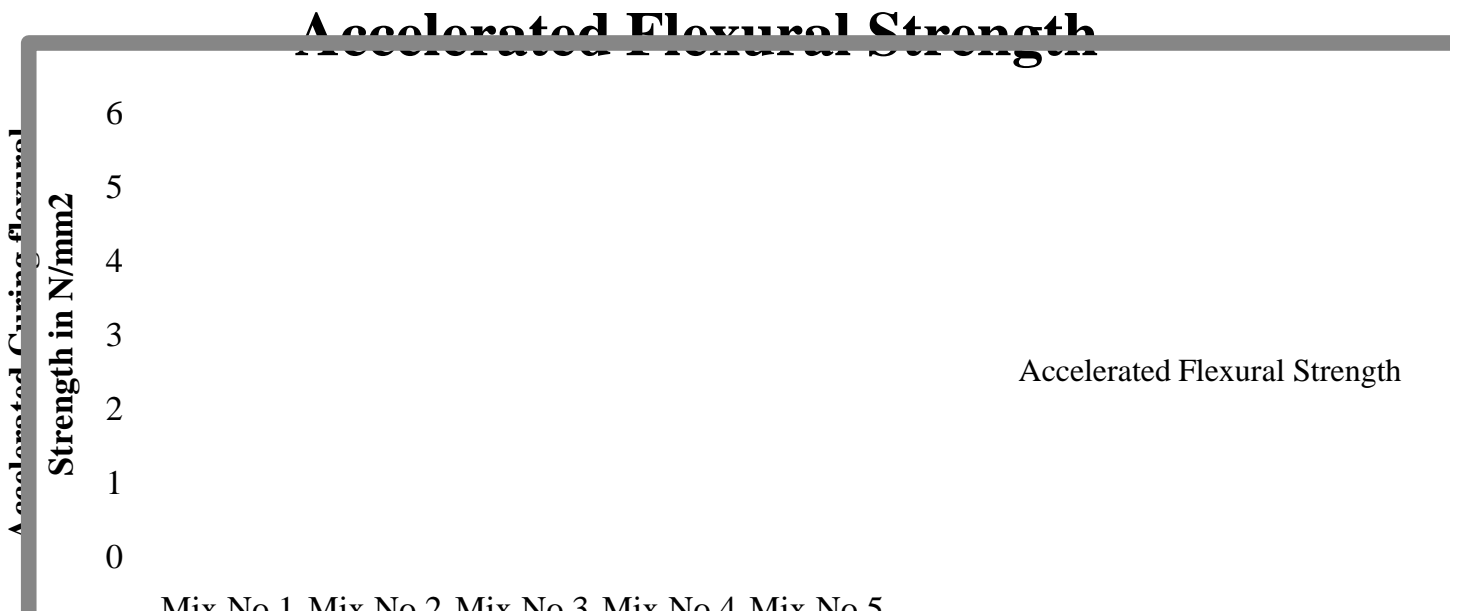

Mix No 1 Mix No 2 Mix No 3 Mix No 4 Mix No 5

Fig 14 Variation of flexural strength with types of mixture with accelerated curing

From Table 7 and Fig 14, it is observed that, the maximum value of flexural strength for accelerated curing 5.55 $\mathrm{N} / \mathrm{mm}^{2}$ is observed at Mixture No. 3 i.e. $10 \%$ Fly ash \& $10 \%$ Metakaolin and further it goes on decreasing .

Also from the test results of flexural strength of concrete increased by accelerated curing as compared to 28 days normal curing but it is also noticed that accelerated curing has a very little effect on flexural strength of concrete.

\section{Conclusion}

The present research focused on studying the effect of fly ash and metakaolin in concrete mix and on strength of concrete and to determine how curing conditions affects concrete strength. Based on the results obtained the following conclusions can be drawn: 
- It is seen that with accelerated curing concrete compressive strength increased with desirable amount and also higher than target strength of concrete.

- It is also seen that fly ash and metakaolin addition in cement has noticeable effect on compressive strength of concrete.

- In case of flexural strength of concrete it is increased upto addition of fly ash $10 \%$ and addition of $10 \%$ Metakaolin in mixture i.e. Mixture No. 3 after that it is considerably start to decrease.

- Early prediction of 7 days and 28 days compressive strength results through simple prediction factor is not possible for concrete mix containing cement replacement materials due to their physical and chemical properties on the rate of strength gain.

- Mathematical model for early prediction of 7 days and 28 days compressive strength of cubes are proposed for OPC cement and blended cement individually. Due to this relation, this method will also helpful for Precast Manufactures.

- It can also be concluded that increase in curing temperature has more favorable effect on the strength gain of concrete with cement and cement replacing material.

\section{Acknowledgements}

This is to acknowledge \& thank all the individuals who played defining role in shaping my project. Without their consent support, guidance \& assistance this project would not have been completed. I acknowledge with thanks, the guidance \& generous help rendered by my Project guide C.R.Nayak \& Co-guide Prof S. B. Walke my, for their valuable guidance, continual encouragement $\&$ advice. I think without their humble support it won't be possible.

I am also thankful to Prof G. N. Narule, the Professor\& Head of the Department of Civil Engineering for supporting as \& when required for their valuable suggestions \& advice during project work.

\section{References}

[1] Mohamed, "Effect Of Fly Ash \& Silica Fume On Compressive Strength Of Self Compacting Concrete Under Different Curing Conditions", Ain Shams Engineering Journal (2011) 2.

[2] Chang, Chen, Wang, Wu, "Performance Of Reactive Powder Concrete (RPC) With Curing Conditions \& Its Retrofitting Effects On Concrete Member", Concrete Repair, Rehabilitation \& Retrofitting II- Alexander Et Al (Eds), London, ISBN 978-0-415-46850-3.

[3] Aminur, Horunur, Zakir, "Effect Of Aggregate \& Curing Conditions On The Compressive Strength Of Concrete With Age", UNIMAS, e-Journal Of Civil Engineering, Vol-1:Issue21april 2010.

[4] Alilou, Tesnehalab, "Prediction Of 28 Days Compressive Strength Of Concrete On $3^{\text {rd }}$ Day Using Artificial Neural Network", International Journal of Engineering (IJE), Vol. 3, issue-6

[5] Lu, Tan, Phoon, "Use Of Elevated Curing Temperature For Accelerated Testing Of Cement Stabilized Dredged Singapore Marine Clay", 2011 Pan-Am CGS Geotechnical Conference.

[6] Hasan, Kabir, "Prediction Of Compressive Strength Of Concrete From Early Age Result", $4^{\text {th }}$ Annual Paper Meet \& $1^{\text {st }}$ Civil Engineering Congress, December 22-24, 2011, Dhaka, Bangladesh.

[7] Caliskan, Turk, Yazicioglu, "Effect Of Curing Condition On The Engineering Properties Of Self Compacting Concrete", Indian Journal Of Engineering And Materials Sciences, Vol-13, Feb 2006, pp-25-29.

[8] Obala, Rodriguez, Ben-Barka, "Effect Of Nonstandard Curing Of Concrete", NRMCA Research Lab-Series D335 \& D338.

[9] I.S: 9013-1978 - Method of Making, Curing \& Determine Compressive Strength of Accelerated Cured Concrete Test Specimens.

[10] Ndihokubwayo, "Compressive \& Flexural Strength For Considerable Volume Fly Ash Concrete", Journal Of Civil Engineering Research-2011; 1(1):21-33.

[11] Makul, Chatveera, Ratanadecho, "Use Of Microwave Energy For Accelerated Curing Of Concrete", Songklanakarin J. Sci. Techol. 31(1), 1-13, Jan-Feb-2009.

[12] Yazdani, Manzur, "Effect Of Steam Curing Of Concrete Piles With Silica Fume", International Journal Of Concrete Structure \& Materials, Vol-4, No.1, Pp-9-15, June.

[13] Vinoth, "Prediction Of Concrete Strength Using Microwave Based Accelerated Curing Parameters By Neural Network", International Journal Of Engineering \& Technology (IJET) Vol-5, No.1 Feb-Mar 2012.

[14] Udoeyo, Robert, Nsan, "Early Prediction Of Laterized Concrete Strength By Accelerated Testing”, IJRRAS-5(1), Oct-2010.

[15] Rao, Kumar, Khan, "A Study On The Influence Of Curing On The Strength Of A Standard Grade Concrete Mix", Architecture \& Civil Engineering, Vol-8, No.1, 2013, Pp- 23-24.

[16] Goyal, Kumar, Bhattacharjee, "Effect Of Relative Proportion Of Pozolana On Compressive Strength Of Concrete Under Different Curing Condition", International Journal Of Engineering, Vol - 2, Issue (1). 